3. Investigations, including diagnostic family interview, revea scapegoating, constant denigration and refusal to allow child to have social contacts outside school hours.

4. Parents refuse family therapy and will not bring Sharon to clinic.

5. Case conference-suspicion of emotional abuse confirmed. GP's information reveals long-standing and apparently intractable personality problems of parents. Local social worker appointed who is able to visit regularly. School undertake to bring Sharon for individual treatment, to which parents agree, provided they do not lose time from work.

6. Informal agreement reached-At Risk Register not used.

7. Continued monitoring by school, visiting social worker and psychiatrist seeing Sharon. Scapegoating diminished. Happier, more normal life for Sharon.

\section{B. Carol, aged 6}

1. Alert - by GP after mother's frequent complaints about Carol. Home visit by health visitor increases concern.

2. Referral to child psychiatric team.

3. Investigation-Carol's fearful, silent and watchful behaviour in presence of mother noted. Carol's normal, happy behaviour in school, with father and with friendly adults noted. No evidence of physical abuse or of neglect. Mother's own ill treatment at hands of her mother whom Carol resembles. Mother seen to function normally with both boys in family.

4. Treatment offered-(a) Family therapy greatly increased mother's hostility and Carol's fear; (b) Individual psycho therapy ofiered to mother in Adult Psychiatric Department.

5. Failure of treatment.

6. Case conference- decision to place Carol on At Risk Register and to provide intensive social work support to mother, father and family in home, a scarce resource locally, in addition to work of child psychiatrist.
7. Carol sent to neighbours but brought home and punished after she had settled down, being punished for being happy away from home. The problems persist and are intractable.

8. Care Order applied for-Carol placed with foster parents and allowed to stay there.

\section{Anne, aged 4}

1. Alert-request by mother for Anne to be taken into care under Section 1, i.e., voluntarily.

2. Anne seen to be almost mute, very limited in social development although physically well.

3. Social workers referred child to child psychiatrist asking if she was autistic.

4. Investigations reveal Anne's potential to socialize normally, and mother's severe personality disorder noted.

5. Rapid improvement in care of foster mother.

6. Parental rights assumed by Local Authority. Anne remains with foster mother who hopes to adopt her.

\section{BIBLIOGRAPHY}

BENTOVIM, A. (1981 Emotional abuse of children. Annotation in Journal of Child Psychology and Psychiatry, in preparation.

Extracts from C.C.E.T.S.W. Report on 'Good Enough Parenting'. (1978) Social Work Today, 9, 29, 21-43.

Frude, N. (ed) (1980) Psychological Approaches to Child Abuse. London: Batsford. (See particularly the chapters by Main and Hyman.)

Garbarino, J. (1978) The elusive 'crime' of emotional abuse. Child Abuse and Neglect, 2, 89-99.

Goodwin, J., GAuthorne, C. G. \& RADA, R. T. (1980) Cinderella Syndrome: Children who stimulate neglect. American Journal of Psychiatry, 137, 1223-25.

\title{
Trainees' Sessions at Annual Meeting
}

As in previous years, the College wishes to encourage psychiatrists in training to present short papers at the Annual General Meeting in London in July. Please submit work of an original nature which should take no longer than ten minutes to present, but contain sufficient material to invite constructive criticism and helpful advice. Papers of a suitable standard will be considered for publication in the British Journal of Psychiatry. Further details may be obtained from Miss Jane Boyce at the College. Please send précis with title to Dr A. J. Poole, Moorhaven Hospital, Ivybridge, Devon PL21 OEX as soon as possible.

\section{Psychiatry honoured}

In March this year Professor Sir Desmond Pond took up a new appointment as Chief Scientist in the Department of Health and Social Security. He succeeds Professor Arthur Buller, Professor of Physiology at Bristol University. 